\title{
Útgjöld ríkisins í Norðausturkjördæmi og tekjur ímyndaðs „Norðausturríkis“
}

\author{
Póroddur Bjarnason, prófessor í félagsfræđi við Háskólann á Akureyri og \\ Jón Porvaldur Heiðarsson, lektor í hagfræđi við Háskólann á Akureyri
}

\section{Útdráttur}

Hlutdeild einstakra landshluta í tekjuöflun pjóðarinnar og skipting ríkisútgjalda milli höfuðborgar og landsbyggða eru meðal umdeildustu mála í íslenskri byggðaumræðu. Slík umræða endurspeglar ólík viðhorf til félagslegs réttlætis og ólíka hagsmuni íbúa mismunandi landssvæða. Prátt fyrir harðvítugar deilur um mikla hagsmuni eru rannsóknir á dreifingu ríkisútgjalda eftir landsvæðum af skornum skammti. Í pessari rannsókn er sjónum beint að útgjöldum ríkisins í Norðausturkjördæmi á grundvelli fjárlaga ársins 2011 og viðbótarupplýsinga sem safnað var hjá einstökum stofnunum og ráðuneytum. Niðurstöður sýna að starfsemi ríkisins á Norðurlandi eystra er um 11\% minni en mannfjöldi segir til um eða sem nemur rúmlega 74 púsund krónum á hvern íbúa á ári. Starfsemi ríkisins á Austurlandi er um 23\% minni en mannfjöldi segir til um eða sem nemur rúmlega 159 púsund krónum á hvern íbúa á ári. Á hinn bóginn leggur ríkið til svipaða upphæð til að stuðla að pví að pjónusta sveitarfélaga sé sambærileg pví sem gerist annars staðar og til að styðja við landbúnað á pessum svæðum. Ef áætlaðar tekjur ríkisins eru bornar saman við útgjöld ríkisins í kjördæminu kemur í ljós að útgjöldin eru hærri sem nemur $625 \mathrm{Mkr}$ eða 1,2\% af skatttekjum miðað við fjárlög ársins 2011. Til samanburðar var halli af rekstri íslenska ríkisins skv. fjárlögum 2011 um 7,9\% eftir vaxtagreiðslur. Petta er vísbending um að ímyndað, sjálfstætt „Norðausturríki“ gæti staðið á eigin fótum en til að svara pví pyrfti pó mun viðameiri rannsóknir.

Efnisorð: Ríkisútgjöld, ríkistekjur, starfsemi ríkisins. 
STJÓRNSÝSLA

\title{
State expenditure in the Northeast district and the income of a hypothetical sovereign "Northeastland"
}

\begin{abstract}
The relative share of different regions in state income and the division of state expenditure between the capital and the countrysides are among the most divisive issues in Icelandic rural policy discourse. This discourse reflects a diversity of attitudes towards social justice and the different interests of different areas. However, there is very little research into the geographical distribution of state expenditures across regions, despite heated arguments over the substantial interests at stake. This research focuses on state expenditures in the Northeast district of Iceland based on the 2011 state budget and additional information collected among various institutions and ministries. Results show that government activities in the east Northland are 11\% less than predicted by population or the equivalent of 74 thousand ISK per inhabitant per year. Government activities in Eastern Iceland are 23\% less than predicted by population or the equivalent of 159 thousand ISK per inhabitant per year. Yet the state contributes a similar amount to ensure that municipal services are similar in the Northeast and regions of the country and to support agriculture in the Northeast region. As an independent "Northeast state" the region would have a budget deficit of 625 million ISK or 1,2\% of total tax revenues based on current state income and expenditure in the region. In comparison the budget deficit of the Icelandic state was 7,9\% after financial costs according to the 2011 state budget. This indicates that a hypothetical, independent "Northeastland" could be viable but further research is needed.
\end{abstract}

Keywords: State expenditure, state income, state activities.

\section{Inngangur}

Í upphafi nítjándu aldar hófst markviss uppbygging Reykjavíkur með skipulögðum flutningi allra helstu menningar- og valdastofnana landsins til porpsins sem pá taldi rétt um 300 íbúa og var pví á stærð við Grenivík eða Djúpavog rúmum tvö hundruð árum síðar. Með peirri ákvörðun hófst veldisvöxtur péttbýlisins á suðvesturhorni landsins jafnframt pví sem forsendur sköpuðust fyrir peirri miðstöð stjórnsýslu, fjármála, viðskipta, fjölmiðla, menntunar og menningarstarfs sem Jón Sigurðsson taldi til dæmis eina meginforsendu sjálfstæðrar pjóðar (एóroddur Bjarnason, 2011). Pannig voru íbúar á núverandi höfuðborgarsvæði orðnir um fjórðungur landsmanna árið 1921 og um helmingur peirra árið 1961. Í ársbyrjun 2012 var svo komið að nærri tveir af hverjum premur Íslendingum bjuggu á höfuðborgarsvæðinu en rúmlega priðjungur utan pess (Hagstofa Íslands, 2012).

pessi íbúapróun hefur orðið ýmsum tilefni til pess að lýsa pví yfir að „landsbyggðin” sé að hruni komin, fólksflóttinn til suðvesturhorns landsins sé óstöðvandi og Ísland sé orðið nokkurs konar borgríki. Pannig telur Ágúst Einarsson (2005) til dæmis að saman- 
borið við önnur lönd sé landsbyggðin nú pegar nánast horfin. Pá hefur Jón Rúnar Sveinsson (2000) lýst pví yfir að baráttunni fyrir jafnvægi í byggð landsins sé lokið með ósigri byggðastefnunnar og landsbyggðin verði héðan í frá einungis bakgarður borgríkisins. Slíkar lýsingar á hnignun landsbyggðanna eru pó mjög orðum auknar. Pótt fólksfjölgun á Íslandi hafi að verulegu leyti komið fram á höfuðborgarsvæðinu hefur próun flestra íslenskra landsbyggða síðastliðna öld einnig einkennst af velmegun, fólksfjölgun og péttbýlisvæðingu (Póroddur Bjarnason, 2011). Verulegrar hnignunar gætir helst í strjálbýli og peim priðjungi smærri péttbýliskjarna sem búa við einhæft atvinnulíf, takmarkaða pjónustu og erfiðar samgöngur.

раð er engum efa undirorpið að sú byggðastefna sem mótuð var í upphafi 19. aldar og fólst í eflingu Reykjavíkur sem miðstöðvar landsins var mikilvægur páttur í framfarasókn íslensku pjóðarinnar á 20. öld (Póroddur Bjarnason, 2012). Pættir á borð við sampjöppun mannauðs, opinberrar starfsemi, fyrirtækjarekstrar og fjárfestinga í innviðum nútímasamfélags á einum stað gegndu lykilhlutverki í umskiptum frá bændasamfélagi sjálfspurftarbúskapar til iðnaðar- og pekkingarsamfélags nútímans. Á sama tíma er ljóst að starfsemi ríkisins og opinber pjónusta í Reykjavík byggðu að verulegu leyti á sköttum íbúa landsbyggðanna sem lengst af störfuðu einkum við frumframleiðslu og afleidda starfsemi og höfðu takmörkuð tækifæri til að nýta sér atvinnutækifæri og pjónustu ríkisins.

Á síðustu árum og áratugum hafa framfarir í samgöngum og samskiptatækni aukið mjög möguleika stjórnvalda til að veita öllum landsmönnum opinbera pjónustu óháð búsetu. Á sama tíma hefur umbylting í menntun, pekkingu og tækni gjörbreytt samfélagsgerð og lífsháttum og skapað áður fjarstæðukennda möguleika á nútímalegri grenndarstjórnsýslu um land allt. Vaxandi krafa skattgreiðenda um að opinber starfsemi og pau störf sem hún skapar séu staðsett í heimabyggð peirra stangast pannig á við sampjöppun allrar starfsemi og stjórnsýslu ríkisins í Reykjavík. Pví má segja að tvískipting landsins í „borg“ og „landsbyggð“ sé á vissan hátt arfleifð aðstæðna og hugsunarháttar 19. og 20. aldar sem engu að síður hefur enn djúpstæð áhrif á opinbera umræðu og stefnumótun nú á fyrri hluta 21. aldarinnar.

Hlutdeild einstakra landshluta í tekjuöflun pjóðarinnar og skipting ríkisútgjalda milli höfuðborgar og landsbyggðanna vítt og breitt um landið eru meðal umdeildustu mála í íslenskri byggðaumræðu. Að hluta til endurspeglar umræðan ólík viðhorf til félagslegs réttlætis og réttinda einstaklinga gagnvart heildinni, en oft virðist hún jafnframt eiga rætur að rekja til ólíkra hagsmuna íbúa mismunandi landssvæða. Pannig hafa íbúar fámennra landshluta eða byggðarlaga oft bent á mikla hlutdeild sinna svæða í útflutningsverðmætum pjóðarinnar (sjá t.d. Austurglugginn, 2012; Bæjarins besta, 2011) en ýmsir hagfræðingar á höfuðborgarsvæðinu lagt áherslu á hagkvæmni pess að auka hlutdeild suðvesturhorns landsins í sjávarútvegi og stóriðju (sjá t.d. Axel Hall o.fl., 2011; Ágúst Einarsson, 2008). Đá virðast mörgum íbúum á höfuðborgarsvæðinu öll hagkvæmnis- og sanngirnisrök lúta að pví að efla pjónustu ríkisins fyrir alla landsmenn í Reykjavík og telja pað kjördæmapot að dreifa slíkri pjónustu um allt land (sjá t.d. Ólafur Stephensen, 2011). Ýmsum íbúum fjarlægari byggðarlaga finnst á hinn bóginn lítil hagkvæmni eða 


\section{STJÓRNSÝSLA}

sanngirni felast í pví að greiða fyrir opinbera pjónustu í mörg hundruð kílómetra fjarlægð (t.d. Dóra Hlín Gísladóttir og Kristinn Hermannsson, 2011).

Grundvöllur velferðarríkisins er sá að pegnar ríkisins skuli njóta sameiginlegrar pjónustu eftir pörfum en leggja til sameiginlegra sjóða eftir getu. Séu útgjöld ríkisins skoðuð út frá pví sjónarhorni er pví eðlilegt að skoða útgjöld á einstökum landsvæðum óháð pví hversu mikið pau leggja af mörkum til ríkissjóðs. Hvað bætur til einstaklinga varðar fara t.d. greiðslur elli- og örorkubóta eftir pví hversu margir eiga rétt á slíkum bótum og námslán eftir fjölda háskólanema og pví háskólanámi sem er í boði á hverju svæði. Með sama hætti fara styrkir til landbúnaðar eftir fjölda og umfangi býla, niðurgreiðsla á húshitun eftir möguleikum til orkunýtingar og framlög úr jöfnunarsjóði eftir stærð og styrk sveitarfélaga. Hins vegar fer landfræðileg skipting ýmissa annarra fjárveitinga ríkisins, svo sem til opinberrar starfsemi, pjónustu og fjárfestinga, eftir pólitískum ákvörðunum Alpingis, ríkisstjórnar og embættismanna ríkisins.

Almennt má búast við pví að starfsemi og pjónusta ríkisins sé hlutfallslega dýrari eftir pví sem byggðin er dreifðari. Pannig kostar meira að halda uppi sambærilegri heilbrigðispjónustu, menntun, löggæslu eða samgöngum eftir pví sem færri einstaklingar nýta slíka pjónustu. Í umræðum um sparnað í ríkiskerfinu er petta stundum tekið til marks um að starfsemi og pjónusta í dreifðari byggðum sé óhagkvæm og pví eigi að skera hana niður. Sé gengið út frá meginreglum velferðarsamfélagsins virðist hins vegar sönnu nær að leggja purfi hærri upphæðir til slíkrar pjónustu en mannfjöldi segir til um.

Ákveðin sampjöppun opinberrar starfsemi er óhjákvæmileg og raunar æskileg fyrir pá sem njóta eiga pjónustunnar. Pannig má til dæmis nefna augljóst óhagræði, kostnað og áhættu sem fylgja myndi pví að dreifa sérhæfori læknispjónustu jafnt og punnt um land allt. Hins vegar er ekki til einfalt og óumdeilt svar við pví hversu mikla áherslu skuli leggja á almenna heilbrigðispjónustu í héraði eða sérhæfða pjónustu í höfuðborginni, né heldur hvernig skipta skuli fjármunum til vegagerðar milli samgöngubóta sem auka öryggi, styrkja byggðir eða skila arðsemi. Petta er sá hluti ríkisútgjalda sem einkum skapar störf og bætir pjónustu og hinn almenni skattborgari finnur helst fyrir. Pví má segja að búferlaflutningar felist í pví að „fólk elti skattana sína“ að pví marki sem pað sækist eftir nálægð við starfsemi og pjónustu ríkisins í Reykjavík og að nokkru leyti á Akureyri.

\section{Gjaldahlutdeild og tekjuhlutdeild einstakra landsvæða}

prátt fyrir líflegar og stundum harðvítugar deilur um mikla hagsmuni sem hér eru í húfi eru rannsóknir á dreifingu ríkisútgjalda eftir landsvæðum mjög af skornum skammti. Vifill Karlsson (2005) rannsakaði landfræðilegt misræmi milli fjármögnunar og umsvifa ríkisins og afleiðingar pess fyrir landshluta á Íslandi. Hann komst að peirri niðurstöðu að 27\% skatttekna ríkisins en 15\% ríkisútgjalda væru tilkomin utan skattaumdæma Reykjavíkur og Reykjaness. Með öðrum orðum yrði næstum önnur hver króna sem íbúar landsbyggðanna greiða í skatta eftir í Reykjavík en hin krónan færi til ríkisútgjalda utan höfuðborgarsvæðisins. Vífill taldi að með pessum tilfærslum á skatttekjum örvaði ríkið jafnframt hagvöxt umtalsvert á Reykjavíkursvæðinu en drægi úr hagvexti utan pess vegna margfeldisáhrifa ríkisútgjalda og einhliða viðskiptatengsla milli pessara svæða. 


\section{STJÓRNMÁL \& \\ STJÓRNSÝSLA}

Svipuð mynd birtist í svari iðnaðarráðherra við fyrirspurn um próun starfa á vegum ríkisins eftir landshlutum (Alpingi, 2007). Par kom fram að árið 2005 voru 82\% ársverka á vegum ríkisins unnin á höfuðborgarsvæðinu en 18\% ársverka utan pess. Баð ár voru íbúar höfuðborgarsvæðisins 63\% pjóðarinnar en íbúar landsbyggðanna 37\%. Pví lét nærri að íbúar landsbyggðanna væru með einn ríkisstarfsmann í vinnu í Reykjavík fyrir hvern ríkisstarfsmann í heimabyggð. Í Norðausturkjördæmi voru liðlega púsund ríkisstarfsmenn árið 2005 en hefðu verið ríflega 2.300 talsins ef peim hefði verið skipt hlutfallslega jafnt milli landshluta eftir mannfjölda.

Dá benti rannsókn Dórodds Bjarnasonar (2011) til pess að Vestfirðingar nytu aðeins um helmings peirrar starfsemi ríkisins sem fólksfjöldi fjórðungsins segði til um. Sé miðað við 2,24\% hlutdeild Vestfirðinga greiði peir til dæmis um milljarð til menntamála á vegum ríkisins. Dar af færi rúmur priðjungur til allra menntastofnana á Vestfjörðum, um priðjungur til annarra menntastofnana utan Vestfjarða og tæpur priðjungur til LíN, annarra sjóða og sameiginlegrar pjónustu í menntamálum. Af 217 milljóna framlagi Vestfirðinga til menningarstofnana, félaga og viðburða færi aðeins 34 milljónir eða tæp 16\% til slíkrar starfsemi í heimabyggð. Á öðrum sviðum væri skiptingin hins vegar í mun meira samræmi við fólksfjölda. Af liðlega 400 milljóna framlagi Vestfirðinga til löggæslu og dómsmála pjóðarinnar var t.d. áætlað að tæp 96\% færu til slíkra verkefna á Vestfjörðum en rúm 4\% til annarra svæða.

Helstu takmarkanir pessara niðurstaðna felast í pví að byggt er á tiltölulega einföldum gögnum um beina ríkisstarfsemi en ýmsir jöfnunarsjóðir, bætur til einstaklinga og styrkir til fyrirtækja og landsvæða eru ekki teknir með í reikninginn. Pótt augljóslega sé mikill meirihluti beinnar starfsemi ríkisins í Reykjavík parf að taka tillit til pess að ríkið styrkir ýmsa sambærilega starfsemi í öðrum landshlutum. Pannig eru t.d. leikarar í Đjóðleikhúsinu ríkisstarfsmenn en leikarar Leikfélags Akureyrar starfsmenn sjálfstæðs félags sem styrkt er af ríki og sveitarfélagi. Pá er eðli málsins samkvæmt meiri kostnaður við t.d. vegagerð og stuðning við landbúnað í hinum dreifðu byggðum en í borgarsamfélagi suðvesturhornsins.

Pessari rannsókn er ætlað að varpa skýrara ljósi á landfræðilega dreifingu ríkisútgjalda með pví að greina nákvæmlega útgjöld og tekjur ríkisins í Norðausturkjördæmi samkvæmt fjárlögum ársins 2011. Í velferðarríki má búast við pví að ákveðin starfsemi ríkisins sé samanpjöppuð í tilteknum pjónustukjörnum á péttbýlum svæðum en jafnframt sé hlutfallslega dýrara að veita pjónustu eftir pví sem svæði eru fámennari og vegalengdir meiri. Pannig sé til dæmis sérhæfðari læknispjónusta veitt á Landspítalanum í Reykjavík en á móti sé almenn heilbrigðispjónusta dýrari á hvern notanda í dreifðari byggðum. Ekki er hægt að meta 'eðlilegt' vægi slíkra pátta með hlutlægum hætti en raunverulegt vægi peirra má miða við gjaldahlutdeild svæðisins eða hlutfall af útgjöldum ríkisins á viðkomandi svæði í samanburði við hlutfall af mannfjölda. Pannig væri slík gjaldahlutdeild í jafnvægi ef 12,3\% útgjalda í tilteknum málaflokki væru í Norðausturkjördæmi par sem 12,3\% pjóðarinnar eru búsett. Rétt er að taka fram að í pví felst ekki gildisdómur um að slíkt jafnvægi sé „rétt“ eða „sanngjarnt“ hlutfall ríkisútgjalda heldur má líta á pað sem tiltekinn viðmiðunarpunkt fyrir byggðapólitíska umræðu um slík mál. 
Í almennri umræðu um sampjöppun starfsemi ríkisins á höfuðborgarsvæðinu og minni pjónustu pess í einstökum landshlutum hefur sú spurning vaknað hvort landsbyggðirnar séu „byrði“ á höfuðborgarsvæðinu eða öfugt. Pannig hefur pví verið fleygt аð margvíslegir byggðastyrkir séu langt umfram pað sem landsbyggðirnar leggi til sameiginlegra sjóða en á móti hefur pví verið haldið fram að skattgreiðendur utan höfuðborgarsvæðisins greiði fyrir margvíslega opinbera pjónustu sem peir geti lítið eða ekkert nýtt sér. Í slíkum vangaveltum felst að grundvallarforsendu velferðarríkisins sé hafnað og krafa gerð um pað að skatttekjur tiltekinna landsvæða standi að öllu leyti undir útgjöldum ríkisins á peim svæðum. Pannig má líta á tekjublutdeild svæðisins sem hlutfall af útgjöldum ríkisins á viðkomandi svæði í samanburði við hlutfall af tekjum ríkisins á svæðinu. Баð samsvarar pví að litið sé á Norðausturkjördæmi sem sjálfstætt ríki sem greiða purfi fyrir ríkisútgjöld með tekjum ríkisins innan landsvæðisins. Í pví felst vitaskuld hvorki mat á rekstrarhæfni slíks ríkis né tillaga um stofnun pess heldur tiltekin nálgun á spurninguna um hvort Norðausturkjördæmi sé byrði á landinu í heild eða leggi fjármuni til starfsemi ríkisins í Reykjavík.

\section{Aðferðir og gögn}

Í pessari rannsókn er sjónum beint að útgjöldum ríkisins á Norðurlandi eystra og Austurlandi án Hornafjarðar samkvæmt fjárlagafrumvarpi ársins 2011. Tekjur ríkisins á pessu landsvæði eru einnig áætlaðar. Pannig er fundin áður nefnd tekjuhlutdeild og útgjaldahlutdeild landsvæðisins. Útgjöld eru auk pess flokkuð eftir ráðuneytum og tegundum starfsemi. Áætlaður 37,3 milljarða halli ársins 2011 samkvæmt fjárlögum er hluti pessara útgjalda, en ekki er tekið tillit til fjáraukalaga ársins 2011. Í mörgum fjárlagaliðum eru sértekjur á móti útgjöldum og pví er miðað við nettóútgjöld ríkisins, p.e. útgjöld umfram tekjur í hverjum fjárlagalið. Skatttekjur ríkisins í kjördæminu eru áætlaðar út frá einstökum tekjuliðum fjárlaga og til pess notuð m.a. skattatölfræði Ríkisskattstjóra (2011). Rannsókna- og próunarmiðstöð Háskólans á Akureyri (RHA) annaðist gagnaöflun samkvæmt verksamningi við Samtök sveitarfélaga í Eyjafirði og Pingeyjarsýslum (Eyping) og Samtök sveitarfélaga á Austurlandi (SSA).

Greining á útgjöldum fór pannig fram að fyrst var grófáætlað hlutfall hvers fjárlagaliðar sem fór til Norðurlands eystra og Austurlands án Hornafjarðar. Oft er pessi skipting augljós par sem ýmsir liðir eru alfarið í öðrum landshlutanum, svo sem Menntaskólinn á Akureyri og Menntaskólinn á Egilsstöðum. Aðrir liðir eru augljóslega utan Norðausturkjördæmis, svo sem Menntaskólinn á Ísafirði, Hrafnista í Hafnarfirði eða Landspítalinn í Reykjavík. Margir liðir eru hins vegar blandaðir og var hlutfallið áætlað í hverju tilfelli fyrir sig. Til dæmis var bótum skipt í samræmi við mannfjölda í einstökum landshlutum pegar öðrum upplýsingum var ekki til að dreifa.

Að pessu loknu var öllum 424 útgjaldaliðum fjárlaganna 2011 raðað í einn lista. Efst á listann var settur sá fjárlagaliður sem samkvæmt grófáætluninni var með mestu útgjöldin í Norðausturkjördæmi. Næst var sá liður sem hafði næstmest útgjöldin og svo koll af kolli. Dví næst voru 103 efstu fjárlagaliðirnir á pessum lista skoðaðir hver um sig og áætlað eins nákvæmlega og tök voru á hve útgjöld peirra voru hlutfallslega mikil 
í Norðausturkjördæmi. Misjafnlega gekk að fá upplýsingar um landfræðilega dreifingu útgjalda í hverjum lið. Í sumum tilfellum var hægt að sjá upplýsingar um pað á netinu, í öðrum tilfellum purfti að leita upplýsinga með pví að óska eftir peim. Petta gekk í flestum tilvikum vel. Í einu tilvikinu var áhugaleysi stórrar ríkisstofnunar svo mikið að veita svör að gripið var til pess ráðs að biðja pingmann að bera fram fyrirspurn á Alpingi til að knýja fram upplýsingar. Fyrir utan efstu 103 liðina á listanum stóð eftir 321 liður sem fyrirfram var búist við að lítið eða ekkert kæmi við sögu í Norðausturkjördæmi. Af pessum „minna greindu liðum“ gaf áðurnefnd grófáætlun að 0,6\% eða 853 Mkr rynnu til Norðurlands eystra en 0,2\% eða $299 \mathrm{Mkr}$ til Austurlands. Til að meta áreiðanleika pessarar grófáætlunar og athuga hvort um kerfisbundið ofmat eða vanmat væri að ræða var dregið úrtak 45 fjárlagaliða úr pessum 321 og peir skoðaðir nánar hver fyrir sig. Af liðunum 45 voru útgjöld til Norðausturkjördæmis að meðaltali 2\% lægri en meðaltalið af ofangreindri grófáxtlun liðanna 321 gerði ráð fyrir. Рað gefur skýra vísbendingu um að grófáætlunin vanmeti ekki greiðslur til kjördæmisins af minna greindum liðum.

Útgjöld ríkisins eru pó ekki öll bundin tilteknum svæðum en slíkum óstaðsetjanlegum greiðslum má skipta í prennt. Árið 2011 voru vaxtagreiðslur ríkisins áætlaðar 73.654 Mkr, greiddur fjármagnstekjuskattur ríkisins $2.200 \mathrm{Mkr}$ og greiðslur til útlanda 10.320 Mkr. Fjármagnstekjuskattur sem ríkið greiðir rennur vitaskuld beint aftur í ríkissjóð og pví kemur sama upphæð fram í umfjöllun um tekjur ríkisins í Norðausturkjördæmi. Greiðslur til útlanda eru af ýmsum toga en par má nefna bætur til einstaklinga búsettra í útlöndum, greiðslur til alpjóðastofnana og hjálparstarfs. Pessi útgjöld öll eru kölluð óstaðsetjanleg en pau útgjöld sem er hægt að greina eftir landshlutum eru hér kölluð staðsetjanleg útgjöld.

Tafla 1 sýnir skiptingu 51,6 milljarða útgjalda ríkisins í Norðausturkjördæmi milli æðstu stjórnar ríkisins og málaflokka einstakra ráđuneyta. Líkt og á landsvísu féll rétt tæplega helmingur allra staðsetjanlegra ríkisútgjalda í Norðausturkjördæmi undir málaflokka velferðarráðuneytisins eða um 24,5 milljarðar króna. Pá féllu um 10,2 milljarðar undir málaflokka innanríkisráðuneytisins, 5,6 undir fjármálaráðuneytið, 5,4 undir mennta- og menningarmálaráđuneytið og 3,9 milljarðar undir sjávarútvegs- og landbúnaðarráðuneytið. Vegna æðstu stjórnar ríkisins og peirra fimm ráðuneyta sem eftir standa var samanlagt um tveimur milljörðum varið í kjördæminu.

Í eftirfarandi greiningu er jafnframt fjallað um útgjöld ríkisins í Norðausturkjördæmi eftir eðli peirra. Í fyrsta lagi eru útgjöld ríkisins til opinberrar starfsemi og pjónustu sem almennur skattgreiðandi nýtur í nærumhverfi sínu. Af peim 220 milljörðum sem íslenska ríkið varði til opinberrar pjónustu og starfsemi skv. fjárlögum 2011 runnu 23,3 milljarðar til Norðausturkjördæmis eða um 45\% allra útgjalda ríkisins í kjördæminu. Í öðru lagi er um að ræða fjárfestingar ríkisins sem komið geta íbúum til góða í framtíðinni. Af tæplega 12 milljarða fjárfestingum ríkisins í innviðum féllu aðeins 2,1 milljarðar til í kjördæminu eða um 4\% ríkisútgjalda í kjördæminu. Í priðja lagi eru bætur til einstaklinga sem eru óháðar búsetu en renna til einstakra landssvæða í samræmi við búsetu peirra sem eiga rétt á slíkum bótum, t.d. vegna aldurs, örorku eða annarra pátta. Af peim 150,7 milljarða staðsetjanlegu bótum sem fjárlagafrumvarpið gerði ráð fyrir eru áætlaðir 17,5 milljarðar 


\section{STJÓRNSÝSLA}

Tafla 1. Útgjöld ríkisins samkvæmt fjárlögum 2011 eftir ráđuneytum (Mkr.)

\begin{tabular}{|c|c|c|c|c|c|}
\hline & $\begin{array}{l}\text { Heildar- } \\
\text { útgjöld }\end{array}$ & $\begin{array}{r}\text { Staðsetjanleg } \\
\text { útgjöld }\end{array}$ & $\begin{array}{r}\text { Norour-land } \\
\text { eystra }\end{array}$ & $\begin{array}{l}\text { Austur- } \\
\text { land }\end{array}$ & $\begin{array}{l}\text { Norð-austur- } \\
\text { kjördæmi }\end{array}$ \\
\hline ÆEðsta stjórn ríkisins & 3.541 & 3.541 & 30 & 7 & 37 \\
\hline Forsætisráđuneyti & 882 & 869 & 0 & 0 & 0 \\
\hline Mennta- og menn.ráđ. & 57.134 & 55.140 & 4.532 & 882 & 5.414 \\
\hline Utanríkisráđuneyti & 9.969 & 5.327 & 114 & 1 & 115 \\
\hline Sjávar- og landbún.ráđ. & 18.632 & 18.517 & 2.787 & 1.153 & 3.940 \\
\hline Innanríkisráđuneyti & 59.905 & 59.159 & 6.287 & 3.865 & 10.152 \\
\hline Velferđarráđuneyti & 209.390 & 206.580 & 19.076 & 5.417 & 24.493 \\
\hline Fjármálaráđuneyti & 61.606 & 59.406 & 4.170 & 1.411 & 5.581 \\
\hline Iðnađarráđuneyti & 4.954 & 4.954 & 493 & 338 & 831 \\
\hline Efnahags- og viðsk. & 3.310 & 3.310 & 61 & 55 & 116 \\
\hline Umhverfisráđuneyti & 6.831 & 6.831 & 588 & 314 & 902 \\
\hline Vaxtagjöld ríkissjóđs & 73.654 & 0 & 0 & 0 & 0 \\
\hline Starfsemi og pjónusta & & 220.072 & 17.863 & 5.422 & 23.285 \\
\hline Fjárfestingar í innviðum & & 11.954 & 944 & 1.173 & 2.117 \\
\hline Bætur til einstaklinga & & 150.671 & 13.459 & 4.065 & 17.524 \\
\hline Styrkir svæða og atvgr. & & 40.937 & 5.872 & 2.783 & 8.654 \\
\hline Samtals & 509.808 & 423.634 & 38.137 & 13.443 & 51.580 \\
\hline
\end{tabular}

til einstaklinga í Norðausturkjördæmi eða um 34\% ríkisútgjalda í kjördæminu. Í fjórða lagi verður fjallað sérstaklega um styrki til einstakra svæða og atvinnugreina. Styrkir til svæða og atvinnugreina voru alls 40,9 milljarðar en af peim runnu tæplega 8,7 milljarðar til Norðausturkjördæmis eða um 17\% ríkisútgjalda í kjördæminu.

Heildartekjur ríkisins á fjárlögum 2011 á rekstrargrunni voru 472.464 Mkr en útgjöld 509.808 Mkr. Раð var með öðrum orðum 37.344 Mkr halli á fjárlögum sem samsvarar $7,9 \%$ af tekjum ríkisins. Fjárlagahallinn er hér meðhöndlaður sem tekjur til að samanburður á gjöldum og tekjum verði ekki villandi.

Tekjur ríkisins í Norðausturkjördæmi voru áætlaðar með pví að skoða 14 stærstu tekjuliði fjárlaga 2011, samtals 85\% af öllum tekjum ríkisins. Í sumum tilfellum er notast við tekjur og gjöld einstaklinga 2011 sem finna má í skattatölfræði á vef Ríkisskattstjóra (2011). Pær tölur eiga við tekjuárið 2010 og eru pær endurstilltar með mannfjöldatölum. Skattatölfræði Ríkisskattstjóra telur raunar sveitarfélagið Hornafjörð til Austurlands og verður að leiðrétta heildartekjur Austurlands án Hornafjarðar sem pví nemur. Dví er gert ráð fyrir að meðaltekjur séu pær sömu í Hornafirði og á Austurlandi. Jafnframt er tekið tillit til mannfjöldabreytinga sem hafa orðið frá miðju ári 2010 til miðs árs 2011.

Tafla 2 sýnir að tekjur ríkisins á Norðurlandi eystra voru áætlaðar 10.520 Mkr vegna virðisaukaskatts, $15.074 \mathrm{Mkr}$. vegna skatta einstaklinga og fyrirtækja og $11.322 \mathrm{Mkr}$ vegna annarra gjalda eða samtals 36.916 Mkr. Hlutur Norðurlands eystra í fjárlagahalla er 2.918 Mkr og teljast tekjur landsvæðisins pví samtals 39.834 Mkr með hallanum. Á Austurlandi hafi tekjurnar verið tekjurnar 4.277 Mkr vegna virðisaukaskatts, $6.563 \mathrm{Mkr}$ vegna skatta einstaklinga og fyrirtækja og 4.738 Mkr vegna annarra gjalda eða samtals $15.578 \mathrm{Mkr}$. Hlutur Austurlands í fjárlagahalla er $1.231 \mathrm{Mkr}$ og teljast tekjurnar pví samtals 16.809 
Tafla 2. Tekjur ríkisins eftir stærstu tekjuliðum ársins 2011 (Mkr.)

\begin{tabular}{|c|c|c|c|c|c|}
\hline Tekjuliður & $\begin{array}{l}\text { Tekjur skv. } \\
\text { rekstrargrunni }\end{array}$ & $\begin{array}{r}\text { Hlutfall af } \\
\text { öllum tekjum }\end{array}$ & $\begin{array}{r}\text { Norourland } \\
\text { eystra }\end{array}$ & $\begin{array}{l}\text { Austur- } \\
\text { land }\end{array}$ & $\begin{array}{r}\text { Norð-austur- } \\
\text { kjörd. }\end{array}$ \\
\hline Virđisaukaskattur & 132.000 & $27,9 \%$ & 10.520 & 4.277 & 14.797 \\
\hline Tekjuskattur & 89.300 & $18,9 \%$ & 6.331 & 2.965 & 9.296 \\
\hline Tryggingagjald & 33.918 & $7,2 \%$ & 2.693 & 1.126 & 3.819 \\
\hline Atvinnutryggingargjald & 30.594 & $6,5 \%$ & 2.429 & 1.016 & 3.445 \\
\hline Fjármagnstekjuskattur & 24.700 & $5,2 \%$ & 1.524 & 580 & 2.104 \\
\hline Gjöld á bensín og olíur1) & 22.320 & $4,7 \%$ & 2.232 & 1.134 & 3.366 \\
\hline Tekjuskattur, lögaðilar & 26.400 & $5,6 \%$ & 2.096 & 876 & 2.973 \\
\hline Áfengisgjald & 10.890 & $2,3 \%$ & 902 & 335 & 1.237 \\
\hline Bifreiðagjöld & 6.380 & $1,4 \%$ & 621 & 243 & 864 \\
\hline Tollar og aðflutningsgjöld & 5.392 & $1,1 \%$ & 589 & 169 & 759 \\
\hline Tóbaksgjald & 4.970 & $1,1 \%$ & 448 & 160 & 608 \\
\hline Eignarskattur einstaklinga & 5.210 & $1,1 \%$ & 164 & 33 & 196 \\
\hline Vörugjald, alm. af innfl. & 3.910 & $0,8 \%$ & 355 & 125 & 481 \\
\hline Gjald vegna Ríkisútvarps & 3.730 & $0,8 \%$ & 310 & 122 & 432 \\
\hline Flutningsjöfnunargjöld & 430 & $0,1 \%$ & 50 & 32 & 82 \\
\hline Ađrar tekjur & 72.750 & $15,4 \%$ & 5.701 & 2.416 & 8.117 \\
\hline Samtals & 472.464 & $100 \%$ & 36.916 & 15.578 & 52.494 \\
\hline Fjárlagahalli & 37.344 & $7,9 \%$ & 2.918 & 1.231 & 4.149 \\
\hline Samtals međ fjárlagahalla & 509.808 & $107,9 \%$ & 39.834 & 16.809 & 56.643 \\
\hline
\end{tabular}

Vörugjald af bensíni 5.1.2.1.25. Sérstakt vörugjald af bensíni 5.1.2.1.30. Kolefnisgjald 5.1.2.1.32. Olíugjald 5.1.2.1.33.

Mkr með hallanum. Heildartekjur ríkisins í Norðausturkjördæma eru samkvæmt pessu áætlaðar 52.494 Mkr en með fjárlagahallanum 56.643 Mkr.

\section{Niðurstöður}

Hér eru útgjöld ríkisins í Norðausturkjördæmi greind með hliðsjón af mannfjölda og skatttekjum ríkisins. Annars vegar er litið til gjaldahlutdeildar Norðurlands eystra og Austurlands án Hornafjarðar sem pess hlutfalls af heildarútgjöldum ríkisins sem samsvarar mannfjölda á peim svæðum. Slík nálgun er í samræmi við pað að Norðausturkjördæmi sé hluti velferðarríkisins Íslands par sem allir eiga jafnan rétt á pjónustu hins opinbera. Hins vegar er tekjuhlutdeild skoðuð sem peir beinu skattar og gjöld sem ríkið innheimtir á pessum landsvæðum. Sú nálgun samsvarar pví að litið sé á Norðausturkjördæmi sem sjálfstætt ríki sem greiða purfi fyrir ríkisútgjöld með tekjum ríkisins innan landsvæðisins.

\subsection{Gjaldahlutdeild í velferðarríki}

Íbúar Norðausturkjördæmis frá Siglufirði til Djúpavogs voru 39.212 talsins að meðaltali árið 2011 eða 12,3\% pjóðarinnar (Hagstofa Íslands, 2012). Par af voru íbúar Norðurlands eystra 19.012 eða 9,1\% en íbúar Austurlands án Hornafjarðar 10.200 eða 3,2\% pjóðarinnar. Gjaldahlutdeild kjördæmisins árið 2011 telst pví vera 12,3\% af öllum útgjöldum ríkisins eða 62.655 Mkr. Samkvæmt pví er hlutdeild íbúa kjördæmisins í vaxtagjöldum ríkissjóðs $9.052 \mathrm{Mkr}$ en 1.539 Mkr í öðrum óstaðsetjanlegum útgjöldum. Staðsetjanleg gjaldahlutdeild Norðausturkjördæmis var pví 52.064 Mkr samkvæmt fjárlögum ársins 2011. 


\section{STJÓRNSÝSLA}

Pegar litið er til staðsetjanlegra útgjalda má sjá af töflu 3 að útgjöld forsætisráðuneytisins og æðstu stjórnar ríkisins voru 37 Mkr í Norðausturkjördæmi en hefðu verið $542 \mathrm{Mkr}$ ef staðsetjanlegum útgjöldum væri dreift á alla landshluta í samræmi við fólksfjölda. Útgjöld pessara stofnana í Norðausturkjördæmi teljast pví vera -505 Mkr lægri en gjaldahlutdeild landsvæðisins segir til um. Мeð öðrum orðum skiptist hlutdeild Norðausturkjördæmis í rekstri pessara stofnana í 37 Mkr útgjöld innan kjördæmisins og 505 Mkr útgjöld utan pess.

Tafla 3. Útgjöld ríkisins og gjaldahlutdeild Norđausturkjördæmi samkvæmt fjárlögum 2011 (Mkr.)

\begin{tabular}{|c|c|c|c|c|}
\hline & $\begin{array}{l}\text { Metin } \\
\text { útgjöld }\end{array}$ & $\begin{array}{l}\text { Gjalda- } \\
\text { hlutdeild }\end{array}$ & Mismunur & Hlutfall \\
\hline \multicolumn{5}{|l|}{ Staðsetjanleg eftir fjárlagalið } \\
\hline Æđðsta stjórn ríkisins & 37 & 435 & -398 & $-92 \%$ \\
\hline Forsætisráđuneyti & 0 & 107 & -107 & $-100 \%$ \\
\hline Mennta- og menningarmálaráđ. & 5.414 & 6.776 & -1.362 & $-20 \%$ \\
\hline Utanríkisráđuneyti & 115 & 654 & -539 & $-83 \%$ \\
\hline Sjávarútv- og landbúnađarráđ. & 3.940 & 2.276 & 1.664 & $73 \%$ \\
\hline Innanríkisráđuneyti & 10.152 & 7.270 & 2.882 & $40 \%$ \\
\hline Velferđarráđuneyti & 24.493 & 25.388 & -895 & $-4 \%$ \\
\hline Fjármálaráđuneyti & 5.582 & 7.301 & -1.719 & $-24 \%$ \\
\hline Iðnađarráđuneyti & 831 & 609 & 222 & $36 \%$ \\
\hline Efnahags- og viðskiptaráđueyti & 115 & 407 & -291 & $-72 \%$ \\
\hline Umhverfisráđuneyti & 901 & 840 & 61 & $7 \%$ \\
\hline Samtals & 51.580 & 52.064 & -484 & $-1 \%$ \\
\hline \multicolumn{5}{|l|}{ Staðsetjanleg eftir tegund } \\
\hline Starfsemi og pjónusta & 23.284 & 27.046 & -3.762 & $-14 \%$ \\
\hline Stofnkostnaður & 2.117 & 1.470 & 647 & $44 \%$ \\
\hline Bætur til einstaklinga & 17.524 & 18.517 & -993 & $-5 \%$ \\
\hline Styrkir til svæða og atvinnugr. & 8.655 & 5.031 & 3.624 & $72 \%$ \\
\hline Samtals & 51.580 & 52.064 & -484 & $-1 \%$ \\
\hline \multicolumn{5}{|l|}{ Óstaðsetjanleg útgjöld } \\
\hline Vaxtagjöld ríkissjóđs & 9.052 & 9.052 & 0 & $0 \%$ \\
\hline Önnur óstađsetjanleg útgjöld & 1.539 & 1.539 & 0 & $0 \%$ \\
\hline Samtals & 10.591 & 10.591 & 0 & $0 \%$ \\
\hline Útgjöld alls & 62.171 & 62.655 & -484 & $-1 \%$ \\
\hline
\end{tabular}

Af fjárlagalið fjármálaráðuneytis voru útgjöld í Norðausturkjördæmi -1.719 Mkr undir gjaldahlutdeild (-24\%) og útgjöld mennta- og menningarmálaráðuneytisins voru -1.362 Mkr undir slíkri hlutdeild (-20\%). Pá voru útgjöld utanríkisráðuneytisins -539 Mkr (-83\%) undir hlutdeild kjördæmisins í mannfjölda pjóðarinnar en efnahags- og viðskiptaráðuneytið -291 Mkr (-72\%) undir slíkri gjaldahlutdeild. Fjárlagaliðir velferðarráðuneytis voru nálægt pari á Norðurlandi eystra en -1.193 Mkr (-18\%) undir gjaldahlutdeild Austurlands. Fyrir kjördæmið í heild er pessi stærsti páttur í útgjöldum ríkisins pví -895 Mkr eða 


\section{STJÓRNMÁL \& \\ STJÓRNSÝSLA}

-4\% undir gjaldahlutdeild. Samanlögð útgjöld ríkisins vegna æðstu stjórnar ríkisins og pessara 6 ráðuneyta í Norðausturkjördæmi voru pví 5.311 Mkr lægri en gjaldahlutdeild kjördæmisins.

Hins vegar voru útgjöld sem falla undir sjávarútvegs- og landbúnaðarráðuneytið $1.664 \mathrm{Mkr}(+73 \%)$ yfir gjaldahlutdeild Norðausturkjördæmis og útgjöld innanríkisráðuneytis $2.882 \mathrm{Mkr}(+40 \%)$ yfir slíkri hlutdeild. Pá voru útgjöld iðnaðarráðuneytis $222 \mathrm{Mkr}(+36 \%)$ hærri en hlutdeild kjördæmisins í heildarmannfjölda og útgjöld umhverfisráðuneytisins $61 \mathrm{Mkr}(+7 \%$ ) yfir slíkri gjaldahlutdeild. Samanlögð útgjöld ríkisins vegna málaflokka pessara fjögurra ráðuneyta voru pví 4.829 Mkr hærri en gjaldahlutdeild Norðausturkjördæmis. Pegar öll staðsetjanleg útgjöld eru lögð saman eru ríkisútgjöld í Norðausturkjördæmi pví aðeins 484 Mkr eða -1\% undir gjaldahlutdeild kjördæmisins.

Sé litið til tegunda staðsetjanlegra útgjalda kemur í ljós umtalsverður munur. Starfsemi og pjónusta ríkisins er -3.762 Mkr eða -14\% undir hlutdeild og bætur til einstaklinga -993 Mkr eða -5\% undir gjaldahlutdeild kjördæmisins. Hins vegar er stofnkostnaður í Norðausturkjördæmi 647 Mkr umfram gjaldahlutdeild eða $+44 \%$ og munar par mest um vegagerð í Vopnafirði. Pessir prír pættir eru pví -4.108 Mkr undir hlutdeild Norðausturkjördæmis. Styrkir til svæða og atvinnugreina eru hins vegar 3.624 Mkr yfir gjaldahlutdeild kjördæmisins. Par skýrist af hærri framlögum úr Jöfnunarsjóði sveitarfélaga (1.970 Mkr umfram gjaldahlutdeild) og stuðningi ríkisins við landbúnað í Norðausturkjördæmi (1.890 Mkr umfram gjaldahlutdeild).

pegar allt er talið eru útgjöld ríkisins í kjördæminu pví sem fyrr segir aðeins $484 \mathrm{Mkr}$ eða um -1\% undir gjaldahlutdeild svæðisins. Íbúar svæðisins njóta hins vegar minni pjónustu ríksins sem nemur 96 púsund krónum á hvern íbúa á ári eða um 384 púsund krónum á hverja fjögurra manna fjölskyldu í Norðausturkjördæmi. Á hinn bóginn leggur ríkið til svipaða upphæð til pess að annars vegar tryggja að pjónusta sveitarfélaga í kjördæminu sé sambærileg pví sem gerist annars staðar og hins vegar til að styðja við landbúnað í kjördæminu. Fyrir almennan íbúa kjördæmisins má pví gera ráð fyrir pví að pjónusta sveitarfélaga sé sambærileg pví sem gerist annars staðar á landinu en pjónusta ríkisins um -14\% minni en meðaltal landsins.

\subsection{Tekjur og gjöld „Norðausturríkis“}

Til pess að meta tekjuhlutdeild Norðausturkjördæmis má ímynda sér kjördæmið sem sjálfstætt ríki, „Norðausturríki“ sem eigi landamæri að „Suðvesturríki“ annars vegar á Tröllaskaga austan Skagafjarðar og hins vegar við Dvottárskriður á mörkum Djúpavogshrepps og sveitarfélagsins Hornafjarðar. Par byggju um 39.212 púsund manns eða um 79\% af íbúafjölda Færeyja, 68\% af íbúafjölda Grænland eða 83\% af íbúafjölda Íslands árið 1801. Skuldauppgjör slíks aðskilnaðar væri flókið en t.d. mætti reikna hlutdeild svæðisins í eignum ríkisins á móti hlutdeild svæðisins í skuldum pess. Hér er pó farin sú einfalda leið að gera ráð fyrir pví að Norðausturríki geri engar kröfur til eigna íslenska ríkisins utan svæðisins og taki ekki á sig neinar skuldir ríkisins. Jafnframt sé petta ímyndaða ríki eigandi allra auðlinda í hafi og á landi en purfi á móti að standa fyrir margvíslegri pjónustu ellegar greiða fyrir pá pjónustu sem veitt væri annars staðar frá. Dannig væri 


\section{STJÓRNSÝSLA}

ímyndað Norðausturríki í svipuðum aðstæðum og Ísland var pegar pað fékk sjálfstæði frá danska ríkinu og sem nágrannar pess á Grænlandi og í Færeyjum standa nú frammi fyrir í sjálfstæðisbaráttu sinni.

Tafla 4. Útgjöld og tekjur Norđausturríkis samkvæmt fjárlögum 2011 (Mkr.)

Norðurland eystra

\section{Útgjöld}

Starfsemi og pjónusta

Stofnkostnaður

Bætur til einstaklinga

Styrkir til svæða og atvinnugreina

Óstađsetjanleg útgjöld

Samtals

\section{Tekjur}

Virđisaukaskattur

Tekjuskattur

Ađrar tekjur

Samtals

\section{Tekjur-útgjöld}

Norđausturríki

Hlutfall af tekjum
17.862

944

13.459

5.872

1.138

39.275

10.520

6.331

20.065

36.916

$-2.359$

$-6,4 \%$

Austurland Norðaustur-kjördæmi

Eins og sjá má af töflu 4 var „Norðausturríki“ rekið með lítilsháttar halla á árinu 2011 ef einungis er litið til skattekna og útgjalda íslenska ríkisins par. Pannig voru beinar tekjur ríkisins á svæðinu $52.494 \mathrm{Mkr}$ en staðsetjanleg og óstaðsetjanleg útgjöld án vaxtagreiðslna metin 53.119 Mkr skv. fjárlagafrumvarpi ársins 2011. Dví var hallinn fyrir kjördæmið 1 heild um - $625 \mathrm{Mkr}$ eða -1,2\% af tekjum. Á Norðurlandi eystra er hallinn -2.359 Mkr eða $-6,4 \%$ en á Austurlandi er afgangur $1.734 \mathrm{Mkr}$ eða $11,1 \%$ af tekjum. Til samanburðar er halli af rekstri íslenska ríkisins skv. fjárlögum 2011 um -7,9\% eftir vaxtagreiðslur.

\section{Umræða}

Í Norðausturkjördæmi í heild er starfsemi og pjónusta ríkisins tæplega -3,8 milljörðum minni en hlutdeild mannfjölda segir til um, par af rúmlega -2,1 milljörðum minni á Norðurlandi eystra en -1,6 milljarði minni á Austurlandi. Sé litið til einstakra liða kemur í ljós að útgjöld til almennrar starfsemi og pjónustu í Norðausturkjördæmi eru í mörgum tilvikum svipuð eða nokkru lægri en hlutdeild mannfjöldans segir til um. Af öllum útgjöldum til heilbrigðismála stendur hlutdeild kjördæmisins til dæmis að fullu undir 11,9 milljarða útgjöldum ríkisins til peirra mála og leggur hátt í milljarð til viðbótar til heilbrigðismála á landsvísu utan kjördæmisins.

Í öðrum tilvikum eru útgjöld til almennrar starfsemi og pjónustu pó langt undir hlutdeild kjördæmisins. Pannig má til dæmis nefna að miðað við 2,6 milljarða framlag ríkisins til Ríkisútvarpsins ætti gjaldahlutdeild Norðausturkjördæmis að vera rúmlega 320 


\section{STJÓRNMÁL \& \\ STJÓRNSÝSLA}

milljónir. Kostnaður stofnunarinnar í kjördæminu er hins vegar í raun áætlaður tæplega priðjungurinn af peirri upphæð. Dví má segja að greiðendur útvarpsgjalds í kjördæminu greiði alla starfsemi stofnunarinnar og leggi til viðbótar ríflega tvöfalda pá upphæð til starfseminnar annarsstaðar, aðallega í Reykjavík. Séu áætlaðar milljarðs tekjur vegna auglýsinga teknar með í reikninginn skekkist pessi mynd enn frekar og útgjöld RÚV teljast aðeins fjórðungur af hlutdeild kjördæmisins.

Starfsemi og pjónusta ríkisins á sviði samgöngumála er helsta undantekningin frá pessu almenna mynstri, en um 26\% slíkra útgjalda Vegagerðarinnar og um 18\% útgjalda vegna flugvalla og flugpjónustu falla til í kjördæminu. Alls er pað um 1,3 milljörðum umfram hlutdeild kjördæmisins í mannfjölda. Til viðbótar var vegagerð í Vopnafirði helsta ástæða pess að fjárfestingar ríkisins í kjördæminu voru um $600 \mathrm{Mkr}$ umfram hlutdeild pess í mannfjölda árið 2011. Pá voru styrkir til svæða og atvinnugreina 3.624 Mkr yfir gjaldahlutdeild kjördæmisins. Рað skýrist af framlögum úr Jöfnunarsjóði sveitarfélaga og stuðningi ríkisins við landbúnað í Norðausturkjördæmi.

раð er grundvallarforsenda velferðarríkisins að allir pegnar pess leggi til sameiginlegra sjóða eftir getu en njóti pjónustu og stuðnings ríkisins eftir pörfum. Út frá pví sjónarmiði er starfsemi ríkisins á Norðurlandi eystra um 11\% minni en mannfjöldi segir til um eða sem nemur rúmlega 74 púsund krónum á hvern íbúa á ári. Með sama hætti er starfsemi ríkisins á Austurlandi (utan Hornafjarðar) um 23\% minni en mannfjöldi segir til um eða sem nemur rúmlega 159 púsund krónum á hvern íbúa á ári. Á hinn bóginn leggur ríkið til svipaða upphæð til pess annars vegar að stuðla að pví að pjónusta sveitarfélaga sé sambærileg pví sem gerist annars staðar og hins vegar til að styðja við landbúnað á pessum svæðum. Pví má segja að pokkalegt jafnvægi sé milli tekna og útgjalda ríkisins en almennir skattgreiðendur fái á hinn bóginn talsvert minna fyrir skattana sína í Norðausturkjördæmi en á höfuðborgarsvæðinu.

Sé hins vegar litið svo á að hver landshluti eigi aðeins rétt á opinberum útgjöldum í samræmi við skatttekjur sem par eru innheimtar mætti hugsa sér Norðausturkjördæmi sem sjálfstætt „Norðausturríki“،. Par byggju tæplega 40 púsund manns eða um 80\% af íbúafjölda Færeyja á svæðinu frá Tröllaskaga austan Skagafjarðar að Hvalnesskriðum norðaustan Hornafjarðar. Pví ríki tilheyrðu auðlindir lands og sjávar norðaustan og austan, par með taldar orkuauðlindir, fiskimið og hugsanlegar olíulindir, sem og vegakerfið, hafnir og núverandi fasteignir íslenska ríkisins á svæðinu. Allar aðrar eignir og skuldir íslenska ríkisins væri Norðausturríki hins vegar óviðkomandi.

Tekjur slíks Norðausturríkis hefðu samkvæmt pessum niðurstöðum verið 52,5 milljarðar á árinu 2011. Tekjur Norðurlands eystra voru 6 milljörðum undir meðaltali landsins en tekjur Austurlands 0,5 milljörðum yfir pví meðaltali. Hvað Norðurland eystra varðar munar hér mest um lægri tekjuskatt, trygginga- og atvinnutryggingagjöld og fjármagnstekjuskatt. Ef kjördæmið væri sjálfstætt ríki sem hvorki ætti tilkall til eigna íslenska ríkisins utan kjördæmamarka né bæri ábyrgð á skuldum íslenska ríkisins eru vísbendingar um að pað gæti staðið á eigin fótum. Miðað við tekjur og útgjöld ríkisins í Norðausturkjördæmi 2011 væri halli á tekjum og útgjöldum um -625 Mkr eða -1,2\% af skatttekjum. 


\section{STJÓRNSÝSLA}

Par af væri halli Norðausturlands -2.359 Mkr en afgangur Austurlands $1.734 \mathrm{Mkr}$, en pessi munur skýrist af hærri skatttekjum á Austurlandi. Til samanburðar var halli af rekstri íslenska ríkisins skv. fjárlögum 2011 um -7,9\% eftir vaxtagreiðslur.

Slíkir útreikningar taka hvorki tillit til kostnaðar Norðausturríkis af peirri pjónustu sem Norðausturkjördæmi nýtur nú í Reykjavík án sérstaks endurgjalds né tekna Norðausturríkis af auðlindum orku og lífríki svæðisins. Peir taka ekki heldur tillit til pess að ýmis viðbótarútgjöld myndu leggjast á sjálfstætt Norðausturríki en hlutdeild pess í núverandi styrkjum til landssvæða og óstaðsetjanlegum kostnaði íslenska ríkisins kæmi par á móti. Loks taka peir ekki tillit til pess að margföldunaráhrif af sjálfstæði og aukinni starfsemi ríkisins kæmi fram í auknum skatttekjum. Til að fá skýrari mynd af pví hvort petta landsvæði gæti staðið undir sér sem sjálfstætt ríki pyrfti pví að gera viðameiri rannsóknir, sérstaklega á pví hversu mikið petta ímyndaða ríki pyrfti að greiða fyrir pjónustu sem pað er nú að fá utan ,landamæranna“. раð er nánast útilokað að reikna petta dæmi til enda af nokkurri vissu en pessi einfalda samantekt tekna og útgjalda ársins 2011 sýnir að Norðausturkjördæmi er við núverandi aðstæður langt frá pví að vera baggi á ríkissjóði Íslands.

Fyrri rannsóknir hafa bent til pess að íbúar landsbyggðanna fái allt að helmingi minni starfsemi og pjónustu ríkisins fyrir skattana sína en íbúar höfuðborgarsvæðisins (Vífill Karlsson, 2005; Póroddur Bjarnason, 2011). Pær niðurstöður sem hér hafa verið kynntar bera eitt kjördæmi saman við landsmeðaltal og eru pví ekki sambærilegar við pessar fyrri rannsóknir. Đá getur reynst varasamt að yfirfæra pessar niðurstöður beint og alhæfa út frá peim hver starfsemi ríkisins sé í öðrum landshlutum eða í landsbyggðunum í heild. Akureyri er langstærsta byggðarlagið utan suðvesturhornsins og starfsemi ríkisins par er ekki dæmigerð fyrir aðra pjónustukjarna landsbyggðanna. Pá eru tekjur og útgjöld á Austurlandi með nokkuð sérstökum hætti vegna mikilla stóriðjuumsvifa. Á sunnanverðu Vesturlandi, vestanverðu Suðurlandi og Suðurnesjum má búast við hlutfallslega minni pjónustu og starfsemi ríkisins vegna nálægðar við höfuðborgina, en um leið er slík pjónusta og starfsemi í seilingarfjarlægð fyrir skattgreiðendur. Á norðanverðu Vesturlandi, Vestfjörðum, Norðurlandi vestra og austanverðu Suðurlandi eru hins vegar ekki sterkar pjónustumiðstöðvar og fjarlægðir til slíkra miðstöðva oft miklar. Dví má búast við pví að á pessum landsvæðum sé hlutfall ríkisútgjalda mun óhagstæðara en í Norðausturkjördæmi.

Til pess að fá hugmynd um hvernig pessar niðurstöður ríma við fyrri niðurstöður má pó áætla muninn á landsbyggðakjördæmum og höfuðborgarsvæðinu. Par sem starfsemi og pjónusta ríkisins er mun meiri á Akureyri en í öðrum byggðarlögum utan höfuðborgarsvæðisins mætti ganga út frá pví að önnur landsbyggðakjördæmi líkist fremur Austurlandi að pessu leyti. Samkvæmt pví væri starfsemi og pjónusta ríkisins í landsbyggðunum samtals 20\% undir landsmeðaltali og höfuðborgarsvæðið par með 13\% yfir landsmeðaltali. Að peirri forsendu gefinni njóta íbúar Norðurlands eystra 27\% minni starfsemi og pjónustu ríkisins en íbúar höfuðborgarsvæðisins. Fyrir Austurland og aðrar landsbyggðir væri petta hlutfall hins vegar 47\% sem er sambærilegt við fyrri niðurstöður rannsókna á pessu sviði. 
Nokkrar takmarkanir eru ennfremur á pessari greiningu sem hafa ber í huga. Hún byggir á fjárlögum ársins 2011 sem bera skýr merki aðhaldsaðgerða eftirhrunsáranna og landfræðileg dreifing tekna og útgjalda kynni að vera með öðrum hætti á velmegunartímum. Pá endurspegla fjárlög vilja ríkisvaldsins en veruleikinn kann að vera með nokkuð öðrum hætti. Í greiningunni er pannig hvorki tekið tillit til fjáraukalaga eða annarra frávika frá sampykktum fjárlögum. Einnig reyndist erfitt að fá upplýsingar hjá einstaka stofnun um landfræðilega skiptingu útgjalda. Ennfremur er rétt að hafa í huga að rannsóknin beinist að starfsemi ríkisins í tilteknum landshlutum en ekki er reynt að meta hversu mikil pjónusta er sótt til annarra landshluta eða annarra landa. Loks er hvorki reynt að meta margfeldisáhrif af starfsemi ríkisins né heldur hversu hátt hlutfall af útgjöldum rennur til kaupa á pjónustu utan kjördæmisins.

Hér hefur verið gengið út frá pví að ákveðið jafnvægi felist í pví að hlutfall mannfjöldans sé pað sama og hlutfall útgjalda á tilteknu landsvæði. Баð er pó rétt að halda pví til haga að starfsemi og pjónusta ríkisins er hlutfallslega dýrari eftir pví sem byggðin er dreifðari. Dví kostar meira að halda uppi sambærilegri heilbrigðispjónustu, menntun, löggæslu eða samgöngum eftir pví sem færri einstaklingar nýta slíka pjónustu á svæði af tiltekinni stærð. Í umræðum um sparnað í ríkiskerfinu er petta stundum tekið til marks um að starfsemi og pjónusta í dreifðari byggðum sé óhagkvæm og pví sé eðlilegt að skera hana niður. Sé hins vegar gengið út frá meginreglu velferðarsamfélagsins um að pjónusta sé veitt eftir pörfum virðist hins vegar sönnu nær að leggja purfi hlutfallslega meira til slíkrar starfsemi og pjónustu á fámennari svæðum.

Loks er beinn samanburður á tekjum og útgjöldum háður ákveðnum takmörkunum. Pannig eru umtalsverð margfeldisáhrif af útgjöldum ríkisins í Reykjavík. Par má nefna margvíslega pjónustu einkaaðila við ríkisstofnanir, útgjöld ríkisstarfsmanna, sampjöppun íbúa og fyrirtækja í nálægð við stjórnsýsluna og mikilvæga pjónustu ríkisstofnana. Sjálfstætt Norðausturríki hefði pannig umtalsverðar beinar tekjur sem nú falla til á höfuðborgarsvæðinu. Á hinn bóginn væru útgjöld vegna pjónustu sem íbúar, fyrirtæki og stofnanir í Norðausturkjördæmi sækja nú til Reykjavíkur án sérstaks endurgjalds. Frekari rannsóknir gætu varpað ljósi á útkomu pess reiknisdæmis.

Loks er rétt að hafa í huga að ímyndað Norðausturríki hefði væntanlega full yfirráð yfir fiskimiðum frá Eyjafirði að Álftafirði, endurnýjanlegum orkugjöfum á svæðinu og hugsanlegum olíulindum norðaustur af landinu. Pá er ólíklegt að Norðausturríkismenn myndu niðurgreiða framleiðslu landbúnaðarafurða til sölu í Suðvesturríki eða öðrum löndum. Auðlindagjöld og aðrar tekjur af nýtingu auðlinda svæðisins gætu pví augljóslega staðið undir umtalsvert meiri opinberri pjónustu en íslenska ríkið veitir nú í Norðausturkjördæmi.

\section{Heimildir}

Alpingi. 2007. Svar iðnaðarráðherra við fyrirspurn Björns Vals Gíslasonar og Puríðar Backman um störf á vegum ríksins. 135. löggjafarping 2007-2008. Pingskjal 387 - 160. mál.

Alpingi. 2012a. Svar mennta- og menningarmálaráðherra við fyrirspurn Kristjáns Pórs Júlíussonar um dagskrár- og framleiðslukostnað Ríkisútvarpsins. 140. löggjafarping 2011-2012. pingskjal 987 - 596. mál. 


\section{STJÓRNSÝSLA}

Alpingi. 2012b. Svar mennta- og menningarmálaráðherra við fyrirspurn Kristjáns Dórs Júlíussonar um kostnað Ríkisútvarpsins vegna launa o.fl. 140. löggjafarping 2011-2012. Dingskjal 1146 - 597. mál.

Austurglugginn, 2012. Mótmæli og samhygð landsbyggðarinnar að skila árangri? http://www.austurglugginn.is/index.php/Frettir/Frettir/Motmaeli_og_samhugur_landsbyggdarinnar_ad_skila_arangri_

Axel Hall, Daði Már Kristófersson, Gunnlaugur Júlíusson, Sveinn Agnarsson og Ögmundur Knútsson. 2011. Greinargerð um hagræn áhrif af frumvarpi til nýrra laga um stjórn fiskveiða samkvæmt pingskjali 1475. Reykjavík: Sjávarútvegs- og landbúnaðarráðuneytið.

Bæjarins besta, 2011. Skilningsleysi á mikilvægi landsbyggðarinnar fyrir hagkerfið. http://bb.is/?PageID $=26 \&$ NewsID $=161973$

Dóra Hlín Gísladóttir og Kristinn Hermannsson. 2011. Efnahags- og samfélagsleg áhrif fyrirhugaðs niðurskurðar á Heilbrigðisstofnun Vestfjarða. Grasrótarhópur á norðanverðum Vestfjörðum.

Erna Bjarnadóttir. 2010. Hagtölur Landbúnaðarins 2010. Reykjavík: Bændasamtök Íslands.

Hagstofa Íslands. 2011. Neysla og verð ýmissa vörutegunda. http://hagstofan.is/Hagtolur/Verdlag-ogneysla/Neysla-og-verd-ymissa-vorutegund, sótt 15. desember 2011.

Hagstofa Íslands. 2012. Meðalmannfjöldi eftir sveitarfélagi, kyni og aldri 1998-2011 - Sveitarfélagaskipan 1. janúar 2012. http://www.hagstofan.is/Hagtolur/Mannfjoldi/Sveitarfelog, sótt 15. júní 2012.

Landlæknisembættið. 2011. Umfang reykinga. Reykjavík: Landlæknisembættið.

Ólafur Stephensen. 2011. Tími óvinsælda. Fréttablaðið 9. október 2010.

Ríkisskattstjóri. 2011. Tekjur og gjöld einstaklinga 2011. http://www.rikisskattstjori.is/stadtolur/ skrar/141_2011.pdf, sótt 15. desember 2011.

Umferðarstofa. 2011. Upplýsingatorg, tölfræði. http://www.umferdarstofa.is/Apps/WebObjects/ US.woa/wa/dp?id=958, sótt 15. desember 2011.

Vífill Karlsson. 2005. Um landfræðilegt misræmi á milli fjármögnunar og umsvifa hins opinbera og afleiðingar pess fyrir landshluta á Íslandi. Borgarnes: Calculus ehf.

Dóroddur Bjarnason. 2010. Hefur landsbyggðin efni á Reykjavík? Háskólasetur Vestfjarða, 22. október 2010.

Póroddur Bjarnason. 2011. Fólksfjölgun á landsbyggðinni? bjóðarspegillinn 2011, ritstj. Ása Guðný Ásgeirsdóttir, Helga Björnsdóttir og Helga Ólafs. Reykjavík: Félagsvísindastofnun Háskóla Íslands.

Dóroddur Bjarnason. 2012. Byggðastefna til framtíðar. Byggðastofnun, sótt 7. október 2011. http:// www.byggdastofnun.is/is/page/byggdastefna_til_framtidar/ 